\title{
Keyworth and Press on basic science
}

\section{Researchers to} decide where

\section{funds go?}

\section{Washington}

In the first coherent statement of the Reagan Administration's thinking on science policy, Dr George (Jay) Keyworth, the president's science adviser, said last week that the scientific community must be prepared not only to help identify areas in need of increased support, but also to say where support should be decreased.

The time of constantly growing budgets across the board had passed, Dr Keyworth said, and the scientific community's "best and most thoughtful judgement" was needed to identify areas to deemphasize as well as those meriting new emphasis. "To those who object to such undertakings, and to all of my scientific colleagues, I must say that if scientists do not make such choices, others will, but with less acuity."

Dr Keyworth was addressing a hearing of the House of Representatives Science and Technology Committee on the implications for science of the present budget reductions. At several points in his testimony, Dr Keyworth claimed that the Reagan Administration was promoting a fundamentally new approach to the government's responsibilities for science and technology. "I am proposing a federal role in research and development which is appropriate to the 1980 s - appropriate to a national mood which calls for increased vigour and acceptance of responsibility by individuals and organizations in the private sector and decreased involvement by the federal government in many of our affairs", Dr Keyworth said.

Yet apart from promoting the need to trim research budgets to fit straitened economic circumstances, much of the substance of what Dr Keyworth had to say was similar to statements to the committee made by his two predecessors, Dr Frank Press, science adviser to President Carter and Dr Guyford Stever, adviser to President Ford. All three stressed the federal government's responsibility to promote basic research as a long-term investment in the future. And all agreed that short-term research and development should primarily be the responsibility of the private sector.

Dr Keyworth, in line with the overall policy of the Reagan Administration, emphasized that science policy had to be carried out in the context of other national policies such as national security, international relations, energy, social services and the economy. "For example, science policy, made without considering econo- mic policy, is irrelevant", he said.

Dr Keyworth's immediate predecessor, Dr Frank Press, now president of the National Academy of Sciences, while accepting the need for financial restraint, gave last week's committee hearing a sharply different view. He advocated a ten-year "compact" between government, industry and universities to establish new national goals for the support of science. This would include commitment to an annual real growth of between 1 and 2 per cent in the scientific research budget; an additional 1 per cent growth to support special "targets of opportunity" in different fields; and a real growth of 1 per cent, equivalent to about $\$ 50$ million a year in the contribution made by industry to university research.

To a large extent, however, the differences in the statements from Dr Keyworth and Dr Press were a reflection more of their different constituencies than of disagreements on substance. Both agreed that there should be a reduction in federal support for "demonstration projects" that should properly be taken over by the private sector. And Dr Press spoke of Dr Keyworth's "courage" in

\section{Spain has the money but not the people}

Science in Spain seems to be embarked on a period of rather heady growth. Money under the direct control of the Spanish science research council, the Consejo Superior de Investigaciones Científicas (CSIC), will triple next year if decisions taken by the lower house of the Spanish parliament are confirmed by Senate. This comes on top of a doubling last year of the centrally administered "funds for research", from which CSIC draws the largest single portion. One sign of how the wind is blowing is the story of a Spanish chemist, recently returned from the United States, in a poorly-equipped CSIC laboratory. In the past few weeks he has found himself spending money "eight or nine hours a day" bringing his laboratory up to scratch; and he has not even had to submit a formal grant application.

CSIC plays a major role in science in Spain, maintaining 23 institutes in the humanities and 77 in natural sciences and employing 1,600 scientists plus 4,400 supporting staff. But the Consejo is not the only beneficiary of increased spending. Parliament has also agreed to create two new research funds, on which universities (and others) will be able to draw: one to be controlled by the Ministry of Industry, and one by the Ministry of Health, together increasing the government research budget by about a quarter.

The regional distribution of support is also becoming a shade more equitable. Whereas some 85 per cent of the central funds for research have usually been spent making uncomfortable decisions about what research projects should be cut.

Responding to a question about press reports that he had recommended the elimination of all new planetary exploration missions by the National Aeronautics and Space Administration (NASA) over the next decade - a proposal being discussed this week by President Reagan and NASA administrator James Beggs - Dr Keyworth emphasized the many scientific gains to be made from space shuttle missions, and suggested that this was one area in which direct scientific comparisons might be made.

Expanding on a theme of several of his earlier speeches, Dr Keyworth told the committee that there were several reasons why the United States could not expect to be preeminent in all scientific fields. $\mathrm{He}$ also warned against the tendency to avoid tough decisions about which projects should be cut by applying cuts uniformly across all fields. "I believe the discipline of making such hard choices will ultimately benefit science, just as the occasional pruning of a tree can promote, rather than retard, its heal."

David Dickson

in Madrid, parliament this year has insisted that 25 per cent be spent in the regions; and the autonomous government of Catalonia is also expected to increase its fledgling research budget next year, from 100 million pesetas (around $£ 500,000$ ) to 200-250 million pesetas.

In total, over the past two years Spanish spending on research and development has nearly doubled as a fraction of gross national product from around 0.3 per cent to 0.5 per cent now - still way below the developed world average of something over 2 per cent but an increase which is already proving difficult to manage.

The problem is people. The truly effective Spanish research community is very small, and there is a government freeze on new appointments. This is having two serious effects, which some feel must be corrected quickly or the new money will be merely wasted.

First, there are not enough highly qualified scientists to act as critical referees in all fields in which Spain would wish to do research; although arrangements have been made for refereeing all proposals, in practice the judging has proved to be imperfect and partisan. An international refereeing system is proposed by those who would survive it; the others - inevitably the majority - resist.

Second, there are too few posts becoming vacant to employ the rising tide of experienced Spanish scientists who wish to return from other countries and make use of the new money. So paradoxically the coffers are open, but there are good 